\title{
FORMATION OF AGRICULTURAL LAND LAYOUT AS AN ALTERNATIVE OF LAND CONSOLIDATION
}

\author{
'Andriy POPOV, ${ }^{2}$ Serhii MOVCHAN, ${ }^{2}$ Serhii KOLOMIIETS, ${ }^{2}$ Ivan LEZHENKIN \\ ${ }^{1}$ Kharkiv National Agrarian University named after V. V. Dokuchayev, Ukraine \\ ${ }^{2}$ Dmytro Motornyi Tavria State Agrotechnological University, Melitopol, Ukraine \\ 'popov_andriy@knau.kharkov.ua, 2sergey.movchan@tsatu.edu.ua
}

\begin{abstract}
The lack of a national strategy (program) for land consolidation, which would be integrated into the country's land policy, led to the adoption in 2018 of the Law of Ukraine № 2498-VIII "On Amendments to Certain Legislative Acts of Ukraine in Respect of the Issue of Collective Ownership of Land, Improvement of Agricultural Land Use Rules, Prevention of Raidership and Stimulation of Irrigation in Ukraine". This law is designed to solve the existing problems of land use concerning the rational use of land parcels. However, the principles declared by the relevant law have not gained practical application to this day. The purpose of the article is to analyse the procedure for the formation of the agricultural land layout to ensure the rational use of land through the exchange of rights of use as an alternative to land consolidation.

A detailed analysis of the Law № 2498-VIII allowed to develop an algorithm for the formation of the agricultural land layout with the purpose to exchange of land parcels and their rights of use. This has allowed approaching the solution of the set problem in a more structured and comprehensive way. It has been established that the permitted exchange of land parcels and rights of use within the agricultural land layout is not a land consolidation either in the classical or in any other sense.

An analysis of the legal provisions of Law № 2498-VIII has revealed their inconsistency with the "Voluntary Guidelines on Responsible Governance of Tenure of Land, Fisheries and Forests in the Context of National Food Security" and best international practice on land consolidation. The existing obstacles to the implementation of the legislation on improving the rules of land use in the agricultural land layout have been found out. Three key causes of their occurrence (technical, legal and organizational) have been identified.
\end{abstract}

Key words: land consolidation, exchange of rights, land parcel, landowner, land user, land layout, lease.

DOI: https://doi.org/10.17721/2413-7154/2020.84.42-54

UDC: $332.37: 63$

Received: November 26, 2020.

Accepted: December 23, 2020.

\section{ФОРМУВАННЯ МАСИВІВ ЗЕМЕЛЬ СІЛЬСЬКОГОСПОДАРСЬКОГО ПРИЗНАЧЕННЯ ЯК АЛЬТЕРНАТИВА КОНСОЛІДАЦІї ЗЕМЕЛЬНИХ ДІЛЯНОК}

\author{
'Андрій ПОПОВ, ${ }^{2}$ Сергій МОВЧАН, ${ }^{2}$ Сергій КОЛОМІЄЦЬ, ${ }^{2}$ Вван ЛЕЖЕНКІН \\ 'Харківський національний аграрний університет ім. В.В. Докучаєва, Україна \\ ${ }^{2}$ Таврійський державний агротехнологічний університет імені Дмитра Моторного, м. Мелітополь, Україна \\ 'popov_andriy@knau.kharkov.ua, ${ }^{2}$ sergey.movchan@tsatu.edu.ua
}

Анотація: Відсутність національної стратегії (програми) щодо консолідації земель, яка б була інтегрована до земельної політики країни, обумовила прийняття у 2018 р. Закон України № 2498-VIII "Про внесення змін до деяких законодавчих актів щодо вирішення питання колективної власності на землю, удосконалення правил землекористування у масивах земель сільськогосподарського призначення, запобігання рейдерству та стимулювання зрошення в Україні". Цей закон покликаний розв'язати існуючі проблеми землекористування щодо раціонального використання земельних ділянок. Проте задекларовані законом засади не набули практичного застосування донині. Метою статті $\epsilon$ аналіз процедури формування масиву земель сільськогосподарського призначення для забезпечення раціонального використання земельних ділянок за рахунок запровадження обміну прав користування як альтернативи консолідації земель.

Детальний аналіз Закону № 2498-VIII дозволив скласти алгоритм формування масивів земель сільськогосподарського призначення щодо обміну земельними ділянками та правами їх користування, який дозволив структуровано і комплексно підійти до вирішення поставленої проблематики. Встановлено, що дозволений обмін земельними ділянками та правами користування в межах масиву земель сільськогосподарського призначення не $\epsilon$ консолідацією земель ані у класичному, ані у будь-якому іншому її розумінні.

Аналіз правових норм Закону № 2498-VIII виявив їх невідповідність “Добровільним керівним принципами відповідального управління з питань володіння та користування земельними, рибними та лісовими ресурсами у контексті національної продовольчої" та кращій міжнародній практиці щодо консолідації земель. Ідентифіковано існуючі перешкоди реалізації норм законодавства щодо удосконалення правил землекористування у масивах земель сільськогосподарського призначення, що дозволило виділити три ключові причини їх виникнення: технічну, юридичну та організаційну.

Ключові слова: консолідація земель, обмін правами, земельна ділянка, землевласник, землекористувач, масив земель, оренда. 
Постановка проблеми. Під час проведення приватизації земель колективних сільськогосподарських підприємств, земельні масиви були поділені на земельні ділянки середньою площею 4 га по Україні за принципом, що кожна земельна ділянка буде використовуватися iㅣ власником окремо. Відповідно, у кожному масиві земель сільськогосподарського призначення було запроєктовано мережу польових доріг для доступу до кожної земельної ділянки. Проте, як показав час, переважна більшість власників земельних ділянок не використовують їх самостійно, а здають їх в оренду агроформуванням. Це призвело до того, що мережа польових доріг так і не була сформована до нині і на практиці розорюється орендарями без будь-яких на те правових підстав і використовуються як рілля.

Стрімкий розвиток ринкових орендних відносин призвів до порушення цілісності масивів земель сільськогосподарського призначення через наявність окремого використання земельних ділянок в межах масиву. Однією з причин $є$ те, що нерідко власники земельних ділянок, що розташовані в межах одного масиву, оформлюють права оренди 3 різними орендарями. Іншою причиною може бути наявність у масиві земель сільськогосподарського призначення громадян, які одноосібно обробляють власні земельні ділянки, так званих одноосібники. У результаті, землекористування, площа якого складається 3 орендованих однією юридичною чи фізичною особою, може не створювати замкненого контуру i набуває таких недоліків у його використанні, як вкраплення земельних ділянок інших землевласників (землекористувачів), черезсмужжя та далекоземелля. 3 метою усунення недоліків сільськогосподарського землекористування орендарі нерідко укладають між собою усні угоди щодо пропорційного обміну орендованих земельних ділянок для більш зручного їх використання. Проте 3 юридичної точки зору, таких орендарів можна звинуватити у самовільному захопленні земельних ділянок.

Особливо гострою проблема порушення цілісності масивів стає при використанні одного масиву зрошувальних земель декількома орендарями i одноосібниками. Оскільки виникають труднощі, пов'язані зі здійсненням поливу поля та проведенням сільськогосподарських робіт для домінуючого (істотного) землекористувача.

Прийнятий у 2018 р. Закон України "Про внесення змін до деяких законодавчих актів щодо вирішення питання колективної власності на землю, удосконалення правил землекористування у масивах земель сільськогосподарського призначення, запобігання рейдерству та стимулювання зрошення в Україні” (далі Закон № 2498-VIII) був покликаний розв'язати більшість вищенаведених проблем землекористування у масивах земель сільськогосподарського призначення і стати запобіжником для порушення прав та інтересів землевласників та землекористувачів. Представники наукової спільноти, практиків та експертів (Kulinich, 2018; Ruden, 2018; Maksymenko, 2019; Yurchenko, 2020) з великим оптимізмом зустріли цей закон та нарекли його законом про консолідацію земель. Вже пройшло майже два роки 3 моменту набрання чинності норм про особливості набуття і реалізації права оренди на земельні ділянки в межах масиву земель призначення, проте задекларовані засади так і не набули практичного застосування донині.

Аналіз останніх досліджень і публікацій. У сьогочасній вітчизняній науковій літературі питанням розвитку консолідації земель сільськогосподарського призначення в Україні та способам іiї проведення приділялася увага немалою кількістю науковців, основними з яких, на нашу думку, є праці A. Мартина й О. Краснолуцького (Martyn \& Krasnolutskyi, 2011), М. Ступеня й Г. Дудич (Stupen \& Dudych, 2015), А. Шворака й Т. Свсюкова (Shvorak \& Yevsiukov, 2014). У своїх працях вони обгрунтовують, що довгострокова оренда, обмін земельними ділянками та іх об'єднання є основними способами проведення консолідації земель сільськогосподарського призначення в сучасних умовах розвитку земельних відносин. 3 набуттям чинності Закону № 2498-VIII (VRU, 2018) окремі теоретичні напрацювання та рекомендації цих авторів втратили своєї актуальності, а зміст відповідного закону щодо запровадження альтернативи консолідації земель через механізм обміну правами користування залишився поза увагою наукової спільноти.

Комплексним аналізом проведення консолідації земель 3 використанням різних методичних підходів для її здійснення в європейських країнах займалися експерти ФАО (FAO, 2003, 2004), van Dijk (2007), Thomas (2006, 2006a), Hartvigsen (2014, 2015), Veršinskas et al. (2020). У вказаних роботах підкреслюється, що консолідація земель у більшості країн еволюціонувала 3 вузькоспеціалізованого заходу, управління земельними ресурсами спрямованого лише на розвиток сільського господарства, до багатоцільового інструменту 3 реалізації різних цілей, таких як розвитку сільського господарства i місцевих громад, відновлення навколишнього середовища, здійснення великомасштабних інфраструктурних проєктів тощо.

Як зарубіжні, так і вітчизняні дослідження наголошують, що розробка та прийняття монолітного і функціонуючого законодавства щодо консолідації земель $є$ фундаментальною основою в процесі реалізації національної програми (стратегіi). Однак практика свідчить (Hartvigsen, 2019), що дуже важко прийняти повністю функціонуюче законодавство 3 першої спроби, тому окремі країни постійно вносять вагомі поправки до свого законодавства після реалізації перших проєктів 3 консолідації земель в рамках національних програм. 
Не виключенням стала й Україна. Не маючи національної стратегії (програми) щодо консолідації земель, усі спроби в країні змінити чинне чи прийняти нове відповідне законодавство закінчувалися фіаско.

Метою дослідження $\epsilon$ вивчення процедури формування масиву земель сільськогосподарського призначення для забезпечення раціонального використання земельних ділянок за рахунок запровадження обміну прав користування як альтернативи консолідації земель. Ця дослідницька проблема буде розкрита за допомогою надання відповідей на чотири питання: 1. Яка процедура формування масивів земель сільськогосподарського призначення? 2. Чи є формування масиву земель сільськогосподарського призначення альтернативою консолідації земель? 3. Чи відповідають правові норми формування масиву земель сільськогосподарського призначення щодо обміну правами користування земельними ділянками кращим міжнародним практикам 3 проведення консолідації земель? 4. Що заважає реалізації норм законодавства щодо формування масиву земель сільськогосподарського призначення?

Дослідження в основному базується на використанні якісних методів, одним 3 яких $\epsilon$ контент-аналіз. Цей метод був використаний для аналізу текстової інформації (публікацій вітчизняних i закордонних авторів, нормативноправових актів) за відповідною тематикою, що забезпечило формалізацію та вимір досліджуваних ознак i дозволило зробити професійні висновки про характер і особливості формування масивів земель сільськогосподарського призначення для забезпечення раціонального використання земельних ділянок. Основним напрямком даної роботи є емпіричне дослідження для отримання емпіричних даних.

\section{Виклад основного матеріалу дослідження}

Формування масиву земель сільськогосподарського призначення

Землевласник(и) i землекористувач(i), які зацікавлені в усуненні просторових недоліків своїх землеволодінь та землекористувань шляхом обміну земельними ділянками та/або належними їм правами користування земельними ділянками, мають сформувати масив земель сільськогосподарського призначення. Під масивом земель сільськогосподарського призначення (МЗСП) розуміється сукупність земельних ділянок сільськогосподарського призначення, що складаються 3 сільськогосподарських та необхідних для їх обслуговування несільськогосподарських угідь (земель під польовими дорогами, меліоративними системами, господарськими шляхами, прогонами, лінійними об'єктами, об’єктами інженерної інфраструктури, а також ярами, заболоченими землями, іншими угіддями, що розташовані всередині земельного масиву), мають спільні межі та обмежені природними та/або штучними елементами рельєфу (автомобільними дорогами загального користування, полезахисними лісовими смугами та іншими захисними насадженнями, водними об'єктами тощо) (VRU, 2003). Для формування МЗСП зацікавленим сторонам спочатку необхідно замовити проведення інвентаризації МЗСП. Рішення про надання дозволу або відмову у проведенні інвентаризації надає: для земель державної власності - орган виконавчої влади, уповноважений здійснювати розпорядження земельною ділянкою; в інших випадках сільська, селищна, міська рада, на території якої розташований масив.

Проведення інвентаризації земель державної власності здійснює Держгеокадастр або його територіальний орган, а в інших випадках - юридичні або фізичні особи, що володіють необхідним технічним i технологічним забезпеченням та у складі яких працюють сертифіковані інженериземлевпорядники. За результатами проведення інвентаризації земель виконавцями розробляється відповідна технічна документація, яка погоджується та затверджується відповіднодо ст. 186 Земельного кодексу України (VRU, 2001), та вносяться відомості до Державного земельного кадастру (ДЗК) про сформовані МЗСГ (з присвоєнням облікового номеру) та земельні ділянки, відомості про які не були внесені до ДЗК.

Після формування МЗСП зацікавлені землевласники i землекористувачі усіх форм власності, розташованих у відповідному масиві, можуть ініціювати обмін (міну) земельними ділянками та обмін належними їм правами користування земельними ділянками шляхом взаємного укладання між ними договорів оренди (суборенди) відповідних ділянок на період дії договору оренди. При укладенні договору суборенди згода орендодавця не вимагається, при цьому орендар залишається відповідальним перед орендодавцем за виконання договору оренди. Припинення дії одного 3 договорів оренди, суборенди земельної ділянки, укладених у порядку обміну правами користування, припиняє дію іншого договору оренди, суборенди, укладеного взамін, про що обов'язково зазначається у таких договорах.

Під час обміну (міни) земельної ділянки державної або комунальної власності, розташованої у МЗСП, на іншу земельну ділянку, розташовану у цьому ж масиві, обидві земельні ділянки повинні мати однакову нормативну грошову оцінку або не перевищувати 10\% різниці між нормативними грошовими оцінками.

Норма Закону № 2498-VIII дозволяє земельні ділянки державної чи комунальної власності під польовими дорогами, запроєктованими для доступу до земельних ділянок, розташованих у МЗСП (крім польових доріг, що обмежують масив), передавати в оренду на сім років без проведення земельних торгів власникам та/або користувачам земельних ділянок, суміжних із земельними ділянками під такими польовими дорогами. Передача в оренду таких ділянок здійснюється за умови забезпечення безоплатного доступу усіх землевласників та землекористувачів МЗСП до 
належних їм земельних ділянок для використання їх за цільовим призначенням. Також, дозволено використовувати земельні ділянки під польовими дорогами, що розташовані у МЗСП (крім польових доріг, що обмежують масив), як для проходу (проїзду) до інших земельних ділянок, так і для вирощування сільськогосподарської продукції.

Особа, якій належить право користування істотною частиною МЗСП (далі - істотний землекористувач), має право орендувати інші земельні ділянки сільськогосподарського призначення, розташовані у такому масиві, а у разі якщо ці земельні ділянки перебувають в оренді, - на одержання їх у суборенду, за умови передачі їх власнику (орендарю) у користування (оренду, суборенду) іншої земельної ділянки, розташованої у цьому ж масиві, на такий самий строк та на таких самих умовах, якщо внаслідок черезсмужжя невикористання таких земельних ділянок створює перешкоди у раціональному використанні земельних ділянок, що перебувають у користуванні цієї особи (VRU, 2018, para. 1).

Істотний землекористувач - це землекористувач, якому належить право користування (оренда, емфітевзис) земельними ділянками, розташованими у масиві земель сільськогосподарського призначення, загальною площею не менш як $75 \%$ усіх земель масиву.

Землевласник або землекористувач, земельна ділянка якого передається в оренду (суборенду) істотному землекористувачу, має право на відшкодування майнової шкоди, завданої йому в результаті такої передачі, у повному обсязі, розмір якої визначається шляхом проведення відповідної оцінки.

Істотний землекористувач 3 метою усунення черезсмужжя та організації раціонального використання свого землекористування в порядку обміну правами користування земельними ділянками письмово звертається до інших власників і користувачів земельних ділянок МЗСП з пропози-цією укласти договір(и) оренди (суборенди). У разі недосягнення згоди щодо укладення договору(ів) оренди (суборенди) такий договір(и) визнається укладеним за рішенням суду, крім окремих випадків, визначених ст. 8-2 Закону України "Про оренду землі” (VRU, 1998), що є підставою для державної реєстрації права оренди (суборенди) земельної ділянки в порядку, визначеному законом. Слід зазначити, що одночасно судом може бути визначений розмір майнової шкоди, завданої укладенням договорів оренди (суборенди), та порядок її відшкодування.

Таким чином, державна реєстрація правочинів (міни, оренди, суборенди) є завершальним етапом формування масивів земель сільськогосподарського призначення щодо обєднання (згуртування) земельних ділянок такого масиву, процедура якого наведена на рис. 1.

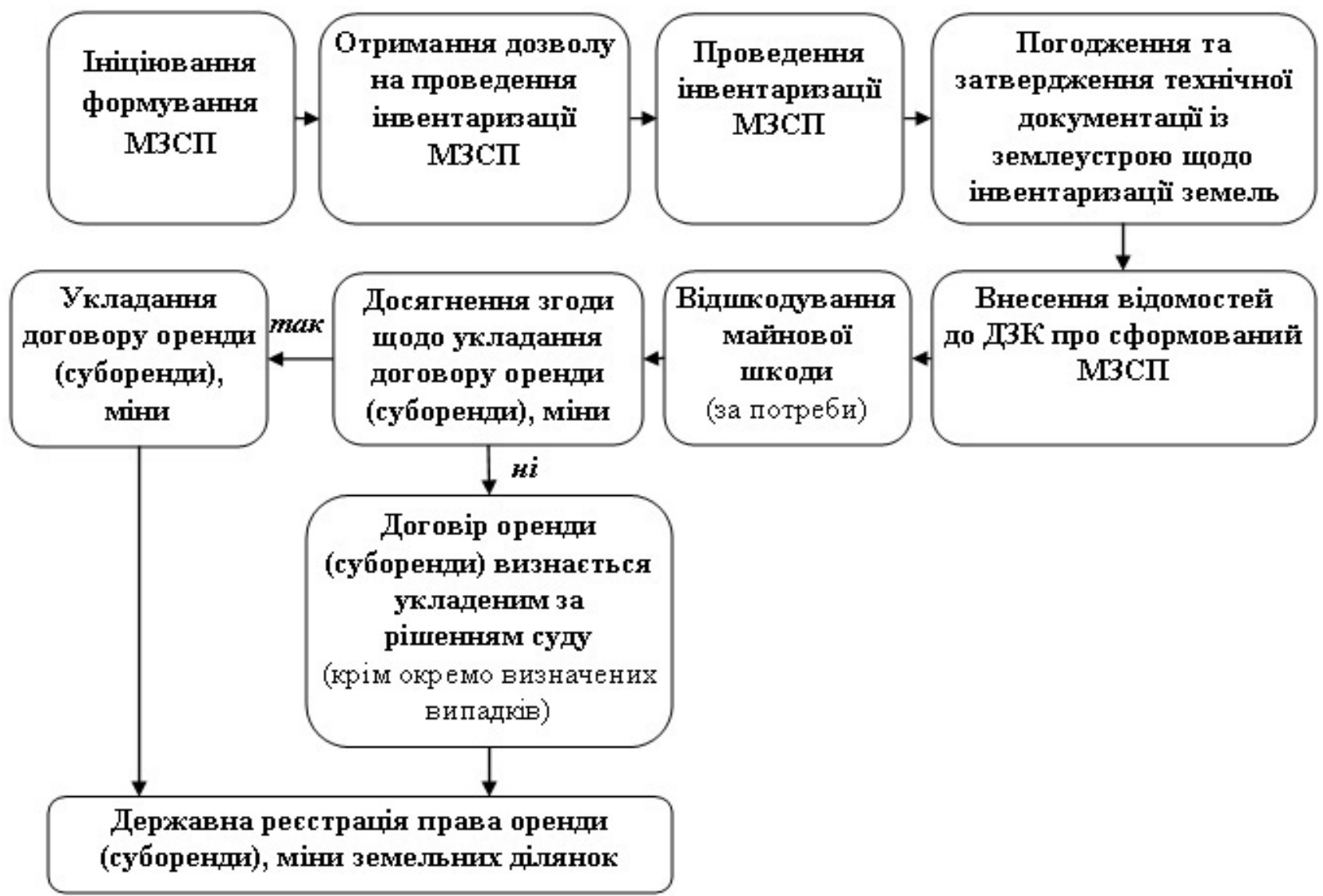

Рис. 1. Алгоритм формування масивів земель сільськогосподарського призначення щодо обміну земельними ділянками та правами їх користування (складено авторами відповідно до VRU, 2018) 
Формування масиву земель сільськогосподарського призначення як альтернатива консолідації земель

Консолідація земель сільськогосподарського призначення нами розуміється як заходи із землеустрою щодо регулювання структури прав власності шляхом координації дій між власниками та користувачами земельних ділянок сільськогосподарського призначення 3 метою формування сталого сільськогосподарського землекористування (Popov, 2016a). Зважаючи на це, формування МЗСП більше нагадує процес самоорганізації землевласників і землекористувачів щодо усунення просторових недоліків своїх землеволодінь (землекористувань), аніж консолідацію земельних ділянок. По-перше, обмін належними землевласникам i землекористувачам правами користування земельними ділянками в межах МЗСП не регулює структуру прав власності - конфігурація, кількість земельних ділянок і ї власників в межах МЗСП залишається незмінною. По-друге, укладання договорів оренди істотним землекористувачем передбачає збільшення площі сільськогосподарського землекористування, проте консолідація земель не завжди сприяє цьому (van Dijk, 2003; Hartvigsen, 2015a). По-третє, формування МЗСП не передбачає розробку плану обміну і оренди (суборенди) земельними ділянками, а отже ці заходи існують і проводяться незалежно один від одного і спрямовані лише на часткове вирішення проблем пов'язаних з фрагментацією земель та просторовими недоліками землекористування. По-четверте, обмін земельними ділянками і належними землевласникам і землекористувачам правами користування в межах МЗСП не передбачають державну реєстрацію прав шляхом подання одного єдиного документа (наприклад, плану обміну і оренди (суборенди) земельних ділянок), що не дозволяє одночасно та економічно ефективно реалізувати проєктні заходи щодо усунення недоліків землекористування. По-п'яте, обмін належними землевласникам i землекористувачам правами користування земельними ділянками в межах МЗСП є лише тимчасовим вирішенням проблем їх раціонального використання і не забезпечує стійкості правового режиму всього землекористування, оскільки є велика ймовірність існування договорів оренди укладених на різні строки, що змусить після закінчення їх строку дії укладати нові договори суборенди без жодних гарантій, що вони будуть укладені на використання тих самих земельних ділянок.

У Законі № 2498-VIII відсутня мета формування МЗСП. Проте, відповідно до обгрунтування необхідності його прийняття та змісту закону, можна зробити висновок, що основною метою формування МЗСП $є$ усунення просторових недоліків (черезсмужжя) землекористування особи, якій належить право користування істотною частиною масиву земель сільськогосподарського призначення, для організації раціонального використання земельних ділянок. Механізмом вирішення цього питання $є$ обмін земельними ділянками та належними правами користування земельними ділянками. Вказана вище мета формування МЗСП є дуже вузькою і спрямована на усунення лише одного 3 багатьох недоліків землекористування найбільш обмеженим способом. Отже, мета формування МЗСП не має нічого спільного 3 метою, завданнями та призначенням консолідації земель. Запропонований механізм формування МЗСП не є консолідацією земель навіть у її класичному розумінні.

Відповідність правових норм формування масиву земель сільськогосподарського призначення щцодо обміну правами користування земельними ділянками кращим міжнародним практикам з проведення консолідації земель

Відповідно до рекомендацій Світової продовольчої організації ООН (ФАО), розробка законодавства щодо консолідації земель має відповідати “Добровільним керівним принципами відповідального управління 3 питань володіння та користування земельними, рибними та лісовими ресурсами у контексті національної продовольчої” (далі по тексту ДКП), які були затверджені на спеціальній сесії Комітету з продовольчої безпеки ФАО у 2012 році після трирічних консультацій 3 громадськістю та урядами країн світу. ДКП стали першим міжнародним інструментом для управління земельними, рибними та лісовими ресурсами, який базується на правах людини, включаючи передачу прав під час ринку земель та реалізації проєктів (програм) з консолідації земель. Наприклад, в одному 3 перших положень (п. 1.1) йдеться про забезпечення реалізації та захист прав вразливих груп населення, розвиток сільської місцевості, охорону довкілля, стабільний економічний та соціальний розвиток. ДКП містить принципи щодо захисту та поваги до законних прав на землю (п. 4.4), впровадження ефективних заходів із запобігання спекуляції та концентрації земель (п. 11.2), забезпечення відповідальних інвестиції у сільське господарство, особливо для дрібних землевласників (п. 12.3), та розвитку механізмів моніторингу якості земельних відносин за участі всіх зацікавлених сторін (п. 26.2) (FAO, 2012). У ДКП цілий Розділ 13 присвячений конкретним регламентам щодо запровадження інструментів консолідації земель на основі кращого міжнародного досвіду.

ДКП в основному підтримують добровільні підходи щодо консолідації земель, особливо якщо це стосується країн в яких інститут приватної власності на землю запроваджений відносно недавно і довіра до державних інституцій є низькою. Це не означає, що консолідація земель за принципом більшості не може бути кращим рішенням у якомусь конкретному випадку. Проте найважливішою передумовою для реалізації такої консолідації земель має бути наявність вагомих гарантій та механізмів оскарження. Потреби громади у консолідації земель i примусова участь зацікавлених сторін можуть бути виправданими лише у тих випадках, коли підхід є комплексним і стосується великої частини території громади (а не тільки окремого поля, як це зазначено 
у Законі № 2498-VIII) за умови прозорої і тісної співучасті з місцевою громадою.

У Законі № 2498-VIII закріплено, що істотний землекористувач, якому у МЗСП належить право користування земельними ділянками загальною площею не менш як 75 \% усіх земель масиву, має першочергове право об'єднувати свої земельні угіддя через отримання переважного права на укладення нових договорів оренди i суборенди в межах масиву та право здійснювати примусовий обмін такими земельними ділянками на строк суборенди. Тобто, це означає, що лише невелика кількість землекористувачів (навіть один землекористувач), які контролюють мінімум 75 \% земель МЗСП, можуть примусити велику кількість дрібних землевласників, які контролюють інші $25 \%$ території відповідного масиву, до участі в обміні правами користування земельними ділянками.

Це положення не відповідає частини четвертої ст. 13 Конституції України (VRU, 1996), в якій зазначається, що саме держава забезпечує захист прав усіх суб'єктів права власності і господарювання, соціальну спрямованість економіки, а усі суб'єкти права власності рівні перед законом. Примусове укладання нових договорів оренди та право здійснювати “примусовий” обмін ділянками на умовах суборенди в межах МЗСП в судовому порядку не забезпечить рівність прав власності усіх власників такого масиву.

Вищенаведена норма суперечить i ДКП, оскільки до уваги береться лише територія. Поріг у 75 \% (кваліфікована більшість) відповідає кращим міжнародним практикам щодо консолідації земель за принципом більшості, але якщо це стосується щонайменше $75 \%$ законних землевласників, які дали згоду на ㄲi проведення і представляють щонайменше $75 \%$ проєктного масиву земель сільськогосподарського призначення. Чіткі і прозорі процедури для застосування консолідації за принципом більшості мають бути розроблені i визначені прямо у Законі, а не залишитися на розгляд органів, що їх реалізовують. Тим не менше, консолідація земель за принципом більшості (примусовий підхід) має залишатися i бути виправданою загальними суспільними потребами загалом і не повинна проводитись для задоволення інтересів одного або кількох істотних землекористувачів (агрохолдингів).

Міжнародний досвід свідчить (Sulonen \& Kotilainen, 2015), що орендарі (землекористувачі) не вважаються учасниками консолідації землі на відміну від орендодавців (землевласників). Це пов'язано 3 тимчасовим характером оренди землі. Крім того, строк дії договору оренди землі впливає на те, наскільки ефективно витрати на консолідацію земель можуть бути розподілені між орендарями як землекористувачами. У країнах, де оренда землі набула широкого застосування і має велику економічну цінність, існують суворіші правила захисту прав орендаря. Тому, в таких країнах статуси орендаря і орендодавця $є$ схожими. $€$ приклади коли (пере)розподіл земельних ділянок проводиться стосовно землекористування, а не власності на землю, за умови, якщо землевласник не заперечує проти цього. Крім того, у багатьох випадках інтереси орендаря переходять до орендодавця.

В Україні законодавством чітко визначено правила оренди земель сільськогосподарського призначення, такі як типовий договір оренди, регульована орендна плата i строки оренди. Ці правила підтримують статус орендаря i довгострокові договори оренди, тим самим дозволяючи орендарю мати деяку стабільність сільськогосподарського землекористування. Стабільність може вплинути на зацікавленість орендаря в поліпшенні земель та умов їх використання, більш активної участі в консолідації землі і іiі фінансуванні. Можна зробити висновок, що в Україні, з наявним інститутом державної реєстрації прав оренди земельних ділянок, права орендарів (землекористувачів) близькі до прав орендодавців (землевласників).

Ми розуміємо, що статус орендодавця $\epsilon$ унікальним, оскільки орендодавці не використовують свою землю власноруч. А тому, вони, як правило, залишаються байдужими, не будучи ні різко негативними, ні позитивними щодо проведення консолідації земель. Така реакція орендодавця, зазвичай, заснована на побоюваннях 3 приводу додаткових витрат на проведення консолідації земель, які вони не можуть розподілити між орендарем чи орендарями. У країнах, де орендна плата за сільськогосподарські землі є високою, орендодавці можуть вважати, що вони і так вже мають достатній дохід від інвестицій (орендної плати), і не вбачають необхідності в отриманні додаткових (наприклад, покращення умов використання земельних ділянок).

Орендодавці визнають консолідацію земель хорошим заходом щодо поліпшення землекористування, але для них це не найкраща інвестиція (Sulonen \& Kotilainen, 2015). Якщо орендар безпосередньо отримує вигоду від консолідації земель як землекористувач, вигоди орендодавця більш непрямі і можуть здаватися менш аргументованими для нього. Незважаючи на те, що орендодавці зазвичай з сумнівом ставляться до консолідації земель, вони не є відверто негативними, і їхнє ставлення може змінюватися під час реалізації консолідації земель. Саме дотримання принципів співучасті і консультацій усіх зацікавлених сторін (які відсутні у Законі № 2498-VIII) під час консолідації земель зможе підвищити інформаційну обізнаність про прямий i непрямий правовий, економічний, соціальний і екологічний впливи від реалізації запланованих заходів.

Не менш важливим є закріплення конкретних положень стосовно участі зацікавлених сторін. У Законі № 2498-VIII не передбачено налагодження зв'язку між усіма землевласниками, землекористувачами, іншими зацікавленими сторонами та громадами на різних етапах формування МЗСП. Більше того, усі процедури щодо формування МЗСП, обміну правами користування і земельними 
ділянками відбуваються без належного інформування усіх землевласників, землекористувачів й інших зацікавлених сторін. Наприклад, укладення договору суборенди між орендарями земельних ділянок сільськогосподарського призначення, розташованих у МЗСП, не потребує згоди орендодавця. Орендарі лише зобов'язані письмово повідомити орендодавця про обмін належними їм правами користування земельними ділянками протягом п'яти днів 3 дня державної реєстрації права суборенди. Така норма закону є неприйнятною і не відповідає передовим міжнародним практикам. Відповідно до ДКП, важливим $\epsilon$ забезпечення рівного залучення усіх зацікавлених сторін, жінок і чоловіків, у формі співучасті та комплексного процесу консолідації земель.

Закон № 2498-VIII не містить чіткого і прозорого механізму оскарження суб'єктами (учасниками) МЗСП дій і рішень ініціатора(ів) формування МЗСП, виконавців інвентаризації МЗСП, планувальника/ підрядника обміну земельними ділянками та правами ï користування або інших осіб у разі виникнення необхідності. За вимогами ДКП, чітке визначення повноважень учасників МЗСП $є$ в обов'язковою умовою проведення заходів щодо передачі прав на землю.

Іншим основоположним принципом, зазначеним у п. 13.1 ДКП, є гарантування того, що становище усіх учасників (навіть під час консолідації земель за принципом більшості) після проведення проєкту консолідації земель має бути, принаймні, не гіршим, ніж до реалізації проєкту. Це забезпечується шляхом запровадження системи гарантій та механізмів оскарження результатів оцінки земель та погодження планів перерозподілу земельних ділянок, які $є$ доступними для усіх учасників проєкту.

Закон № 2498-VIII містить дещо схожі положення. Так, істотний землекористувач має право у межах МЗСП орендувати та брати в суборенду інші земельні ділянки сільськогосподарського призначення, за умови передачі їх власнику (орендарю) у користування (оренда, суборенда) іншої земельної ділянки, розташованої у відповідному масиві, на такий самий строк та на таких самих умовах. Ми впевнені, що на практиці ця норма стосується суто юридичної сторони дотримання умов договорів (строк користування, розмір орендної плати). Проте, у випадку порушення умов використання земельної ділянки, погіршення якості грунту, розвитку ерозійних процесів чи заподіяння іншої шкоди орендар не матиме серйозних наслідків. Тим паче, на сьогодні відсутні дієві механізми відповідальності орендаря за завдану шкоду земельній ділянці.

Сучасне законодавство України не встановлює чіткого та структурованого порядку щодо обігу прав користування і обміну земельними ділянками в межах МЗСП як альтернативи консолідації земель. Важливою передумовою успішної реалізації заходів щодо консолідації земель, з врахуванням унікальних місцевих умов, є закріплення у законі як мінімум трьох основних етапів: техніко-економічного обгрунтування, перерозподілу земельних ділянок та впровадження (FAO, 2012). А рішення про проведення консолідації земель надається лише після того, як протягом першого етапу встановлено іiі доцільність та здійсненність.

Закон № 2498-VIII не встановлює положення (вимог) щодо заявок або погодження ініціювання інвентаризації МЗСП з метою подальшого здійснення обміну земельними ділянками та правами ï користування для усунення черезсмужжя у межах відповідного масиву. Це означає, що процес проведення інвентаризації МЗСП не гарантуватиме зацікавленим землевласникам та/або землекористувачам подальшої успішної організації раціонального використання їх земельних ділянок в межах відповідного сформованого масиву. Іншими словами, проведення інвентаризації МЗСП не зобов'язує власників та/або користувачів, земельні ділянки яких розташовані у такому масиві, до так званої “консолідації земель”. Передовий досвід свідчить, що на стадії ініціювання має запитуватися лише початкова інформація без стягування будь-яких адміністративних зборів, а сам порядок повинен бути на стільки простим і зрозумілим, на скільки це можливо.

У Законі № 2498-VIII не встановлено необхідність розробки плану обміну i оренди (суборенди) земельних ділянок, а тому і відсутній механізм, за яким забезпечувалася б одночасна та економічно вигідна реалізація змін у власності та користуванні земельними ділянками у межах МЗСП. Тому, реалізація змін прав на землю відбуватиметься шляхом укладання великої кількості цивільноправових правочинів i договорів за звичайними процедурами державної реєстрації прав та із застосуванням традиційних адміністративних зборів. Проте, у ДКП (FAO, 2012) зазначається, що під час консолідації земель, як за добровільним підходом так i за принципом більшості, перерозподіл земельних ділянок має бути реалізовано i зареєстровано як “єдиний план”, а не як набір двосторонніх правочинів (трансакцій).

Зауваження викликає законодавча норма, згідно якої,ініціатор обміну правами користування земельною ділянкою визначає суб'єкта оціночної діяльності для встановлення розмір майнової шкоди, завданої власнику чи користувачу ділянки в результаті такої передачі. Вважаємо, що таке положення містить корупційну складову через конфлікт інтересів. Ініціатор обміну вибирає суб'єкта оціночної діяльностіі сплачує вартість його послуг, а це може вплинути на об'єктивність та/або неупередженість результатів оцінки. Спираючись на міжнародний досвід (FAO, 2012), найбільш вірним було б сформулювати положення так, щоб право вибору суб'єкта оціночної діяльності надавалося власнику або користувачу земельної ділянки, якій була задана майнова шкода в результаті обміну правами користування, а оплату послуг залишити за ініціатором такого обміну. 


\section{Перешкоди реалізації норм законодавства щчодо формування масиву земель сільсько- господарського призначення}

Одним 3 головних завдань прийняття Закону № 2498-VIII є створення ефективного механізму використання масивів земель сільськогосподарського призначення шляхом усунення черезсмужжя (“шахматки”) в середині відповідних масивів через механізм добровільного і примусового (в судовому порядку) обміну правами користування земельними ділянками шляхом взаємного укладання між землевласниками i землекористувачами договорів оренди і суборенди відповідних ділянок. У свою чергу, це позбавить недобросовісних орендарів, які фрагментовано орендують земельні ділянки посеред поля (МЗСП), важелів впливу на аграрне підприємство - передумов для “земельного рейдерства”. Проте ця процедура не набула практичного застосування та виявилася відірваною від реальних правовідносин щодо обміну правами користування земельними ділянками через цілу низку причин.

Однією 3 таких причин $\epsilon$ бюрократично обтяжлива процедура отримання статусу істотного землекористувача для організації раціонального використання земельних ділянок шляхом укладання договорів оренди та/або суборенди (у т.ч. на умовах переважного права) 3 рештою земельних ділянок сільськогосподарського призначення у МЗСП. Перш за все, це пов'язано з необхідністю отримання рішення про інвентаризацію МЗСП від органу виконавчої влади, уповноваженого на здійснення розпорядження земельними ділянками або рішення сільської, селищної, міської ради, на територій якої знаходяться землі. Тобто, потенційний істотний землекористувач повинен ініціювати та провести інвентаризацію МЗСП з метою отримання офіційного статусу такого землекористувача. Проте, Закон № 2498-VIII не містить чітких положень щодо змісту і форми заяви та погодження ініціювання проведення інвентаризації МЗСП. Так, не визначено хто може виступати ініціатором інвентаризації МЗСП - землевласник, землекористувач чи група землевласників та/або землекористувачів, а також мінімальний процентний поріг, який вони можуть представляти від усього МЗСП. Також, не закріплено чіткий перелік необхідних документів, які повинні пред'явити зацікавлені землевласники та/або землекористувачі до відповідних органів виконавчої влади чи місцевого самоврядування, для отримання рішення про проведення інвентаризації МЗСП.

Чинне законодавство передбачає, що підставою для проведення інвентаризації МЗСП $€$ отримання дозволу на розробку технічної документації із землеустрою щодо інвентаризації земель буде залежати від форми власності (приватна, комунальна чи державна), але не визначена ієрархія і порядок прийняття рішення у випадку, коли МЗСП включатиме як приватні, так комунальніі державні землі. Слід зауважити, що до проведення інвентаризації МЗСП висуваються такі ж вимоги до складання технічної документації із землеустрою як і до «звичайної» інвентаризації земель, що на нашу думку не є логічним і правильним рішенням.

Не менш дискусійним $є$ механізм реалізації положення щодо розробки технічної документації iз землеустрою щодо інвентаризації земель на замовлення істотного землекористувача. Так, відповідно до частини першої ст. 26 Закону України «Про землеустрій» (VRU, 2003), замовниками документації із землеустрою можуть бути органи державної влади, Рада міністрів Автономної Республіки Крим, органи місцевого самоврядування, землевласники i землекористувачі. У нашому випадку замовником документації із землеустрою буде виступати землекористувач,який представляє $75 \%$ МЗСП, що унеможливлює подальше замовлення розробки відповідної документації, укладення договору 3 розробником. Також, не зрозуміло, хто фігуруватиме замовником технічної документації із землеустрою щодо інвентаризації земель у ситуації, коли ініціаторами інвентаризації МЗСП виступатимуть кілька землевласників та/або землекористувачів.

Успішність формування МЗСП та організації раціонального використання земельних ділянок в середині масиву залежить від наявних фінансових ресурсів. Закон № 2498-VIII, фактично, залишає відкритими усі можливості фінансування. Проте, створюється враження, що законотворець таким чином перекладає вирішення існуючих проблем забезпечення ефективного механізму використання масивів земель сільськогосподарського призначення виключно на землевласників i землекористувачів або істотного землекористувача такого масиву. Саме на них,під час проведення інвентаризації МЗСП та виготовлення документації із землеустрою, перекладається весь тягар (у т. ч. фінансовий) вирішення наступних загальнодержавних проблем пов'язаних 3:

наповненням системи ДЗК повними і актуальними відомостями про його об'єкти шляхом внесенням до ДЗК відомостей про сформовані земельні ділянки у межах МЗСП, відомості про які не були внесеними до ДЗК. В першу чергу це стосується невитребуваних i нерозподілених земельних ділянок, земельних ділянок сільськогосподарського призначення під польовими дорогами, земельних ділянок сільськогосподарського призначення під полезахисними лісовими смугами та іншими захисними насадженнями, які обмежують МЗСП та земельних ділянок, розташованих уздовж такого масиву;

- виправленням помилок у відомостях ДЗК щодо сформованих земельних ділянок у межах МЗСП. У переважній більшості це стосуватиметься встановлення відповідності фактичного землекористування (меж та конфігурації земельних ділянок) відповідно до правовстановлюючих документів та документації із землеустрою на ці земельні ділянки.

Таким чином, отримання статусу істотного землекористувача в межах МЗСП вимагає великих 
фінансових та часових витрат на обтяжливу процедуру інвентаризації земель та формування усіх земельних ділянок в межах такого масиву, навіть за умови, якщо істотний користувач у майбутньому не зацікавлений набувати їх у користування. У подальшому, при раціональній організації земельних ділянок, істотний землекористувач зіштовхнеться ще з однією додатковою, не менш коштовною (Popov, 2019), статтею витрат - розходи на реєстрацію прав оренди та суборенди земельних ділянок.

Іншою перепоною для встановлення статусу істотного землекористувача є відсутність технічної можливості включення відомостей до ДЗК про МЗСП і присвоєння йому облікового номера об'єкта ДЗК за результатами проведення відповідної інвентаризації земель, хочадля цього існують усі законні та підзаконні підстави. За словами представників Держгеокадастру технічна можливість реєструвати земельні масиви з'явиться лише у 1 кварталі 2021 р. (Slaston, 2020).

Закон № 2498-VIII передбачає можливість обміну правами користування земельними ділянками, які розташовані в одному МЗСП (в межах одного поля). На практиці ж,під час проведення заходів щодо раціональної організації землекористування в межах масиву (усунення черезсмужжя та згуртування земельних ділянок), може виникнути потреба у обміні земельними ділянками, які можуть знаходитись у різних МЗСП. Проте на законодавчому рівні здійснити такий обмін неможливо. Також, ефективність раціональної організації земельних ділянок в межах МЗСП обмежена тим, що обмін правами користування здійснюється лише шляхом укладання договорів оренди та суборенди земельних ділянок. На практиці може виникнути ситуація, коли в межах МЗСП знаходяться земельні ділянки, які не можуть передаватися у вторинне користування. Це стосується користування земельними ділянками на правах емфітевзису та постійного користування. Отже, механізм обміну правами користування земельними ділянками дозволяє лише частково та локально вирішити проблеми землевласників i землекористувачів пов'язаних 3 існуючою фрагментацією земель сільськогосподарського призначення.

Слід зазначити, що хоча Закон № 2498-VIII і не передбачає можливість обмінуземельними ділянками між різними МЗСП, на захист сільськогосподарських землекористувачів / землевласників та укладених ними договорів може стати наявна судова практика i Рішення Європейського суду з прав людини в справі “Зеленчук та Цицюра проти України”.

Після проведення інвентаризації МЗСП, особи, які зацікавлені у створенні ефективного механізму використання такого масиву (“консолідації” земельних ділянок), повинні самостійно вибрати найбільш прийнятний і можливий спосіб з урахуванням того, чи $є$ вони землевласниками, землекористувачами i чи можуть набувати землі сільськогосподарського призначення у власність. Законом № 2498-VIII закріплено фактично лише два таких способи: 1) обмін (міна) рівноцінними земельними ділян- ками, нормативна грошова оцінка яких $\epsilon$ рівною або відрізняється не більше, ніж на $10 \%$; 2) обмін належними правами користування земельними ділянками шляхом взаємного укладання договорів оренди і суборенди відповідних ділянок. Істотний землекористувач може набувати окремого правового статусу, якщо його сільськогосподарське землекористування характеризується черезсмужжям, що створює перешкоди у раціональному використанні земельних ділянок. У такому випадку він має право здійснювати як добровільний, так i примусовий обмін належними йому правами користування земельними ділянками шляхом взаємного укладання між землевласниками i землекористувачами договорів оренди (у т. ч. на умовах переважного права) та суборенди (без згоди орендодавця) відповідних ділянок в межах МЗСП. Можна припустити, що власники та/або орендарі не будуть зацікавлені у добровільному обміні в умовах високої конкуренції на ринку оренди земельних ділянок та рівня орендної плати. Тому, на перший погляд, закріплення правової норми щодо застосування примусового обміну належними правами користування земельними ділянками в судовому порядку виглядає логічним рішенням. Проте не слід забувати, що, за рекомендаціями ФАО (FAO, 2012), використання добровільного підходу є найбільш прийнятними для країн з відносно молодим інститутом приватної власності на землю і з низькою довірою до державних інституцій.

Слід відмітити, що процедура обміну правами користування земельними ділянками $є$ єдиним більш-менш врегульованим положенням Закону № 2498-VIII. Але складність його реалізації полягає в тому, що така процедура практично не підтверджена судовою практикою. Можливою причиною цього $є$ те, що ділянки всередині МЗСП не представляють інтересу для третіх сторін і питання вирішуються взаємовигідно для учасників обміну.

Одним із заходів боротьби 3 черезсмужжям $€$ передача в оренду (без проведення земельних торгів) земельних ділянок державної чи комунальної власності під польовими дорогами, запроєктованими для доступу до земельних ділянок, розташованих у МЗСП (крім польових доріг, що обмежують масив), здійснюється за умови забезпечення безоплатного доступу усіх землевласників та землекористувачів до належних їм земельних ділянок для використання їх за цільовим призначенням. Але сільськогосподарські землекористувачі (орендарі) не поспішають орендувати такі землі, оскільки чинним законодавством чітко не визначені порядок погодження між усіма зацікавленими сторонами i процедура передачі їх у користування. Тим більше, суперечливою $€$ правова норма щодо передачі земельних ділянок державної чи комунальної власності під польовими дорогами в межах МЗСП в оренду на однаковий термін (сім років) як для богарних, так i меліорованих земель. Мінімальний строк дії договору оренди земельних ділянок меліорованих земель i на яких проводиться гідротехнічна меліорація не може бути меншим 10 років (VRU, 1998, art. 19). 
Запропоновані заходи щодо обміну існуючими правами користування земельними ділянками 3 метою раціональної їх організації так і не стали запобіжниками в протидії рейдерству. На сьогодні все ще залишається актуальною схема штучного створення черезсмужжя шляхом підкупу власників земельних ділянок, для визнання діючих договорів оренди недійсними. Відповідне рішення приймається Міністерством юстиції України на підставі заяв землевласників про те, що вони не підписували чинні договори оренди, що автоматично призведе до припинення дії договору суборенди. Також, на практиці може трапитися така ситуація, коли 3 тих чи інших причин один із договорів суборенди буде розірваний, припинений або визнаний недійсним у судовому порядку (наприклад власником землі чи спадкоємцями та ін.). Відповідно такі (навмисні або ненавмисні) дії не лише порушать цілісність сільськогосподарського землекористування, але й піднімуть питання щодо прав на посіви та урожай сільськогосподарської продукції.

На нашу думку, закріплений примусовий обмін правами користування земельними ділянками в судовому порядку навряд колись буде застосований на практиці. Навіть самі автори (Kulinich, 2018) Закону № 2498-VIII визнають, що у разі недосягнення домовленості між істотним землекористувачем та/або власником/користувачем земельної ділянки, справа до суду не буде доходити через великі часові та фінансові витрати на їх розгляд. Основною причиною закріплення такого положення - це створення необхідного стимулу для досягнення добровільної згоди. Але з іншого боку примусовий підхід може бути використаний істотним землекористувачем як інструмент тиску на власника/користувача земельної ділянки. Так чи інакше примусовий підхід встановлює додатковий тягар на власника земельної ділянки, оскільки змушує його у разі незгоди на надання земельної ділянки в суборенду звертатися до суду за захистом своїх прав.

Слід наголосити, що Законом № 2498-VIII,що ані для добровільного, ані для примусового підходів, не визначено процедури розробки плану обміну (міни) і оренди (суборенди) земельними ділянками та надсилання пропозицій землекористувачам та землевласникам щодо укладання відповідних договорів, які використовують земельні ділянки в межах МЗСП. Повністю відсутні ключові процедури обговорення та механізми оскарження плану обміну (міни) і оренди (суборенди) земельними ділянками. Слід наголосити, що під час реалізації вищеперерахованих заходів не відбувається жодного обміну інформацією з усіма зацікавленими сторонами МЗСП та територіальною громадою через місцеві засоби масової інформації та інші джерела комунікації. Це лише сприятиме поглибленню кризи довіри до державних інституцій та збільшенню недовіри до впроваджуваних реформ, а також може дискредитувати консолідацію земель, як ефективний механізм формування сталого сільськогосподарського землекористування, в очах землевласників і землекористувачів.
На перший погляд, закріплена Законом № 2498-VIII процедура обміну існуючими правами користування земельними ділянками може здаватися одноразовим заходом щодо раціональної організації цілісності сільськогосподарського землекористування та/або МЗСП. Проте з правової точки зору, проведення такої процедури може виявитися багаторазовим, особливо якщо це стосуватиметься укладання договорів суборенди. Це пов'язано з тим, що закінчення строку, на який був укладений договір оренди, тягне за собою автоматичне припинення договорів, укладених у порядку обміну правами користування. Враховуючи ситуацію існуючої фрагментації термінів оренди земельних ділянок в межах окремого поля(ів) сільськогосподарського землекористування, періодично виникатиме необхідність в переоформленні договорів оренди для кожної окремої ділянки такого поля. У свою чергу це призводитиме до періодичних додаткових витрат на державну реєстрацію права суборенди, а у випадку відсутності істотного землекористувача в межах МЗСП - до боротьби за збереження цілісності землекористування.

\section{Висновки 3 проведеного дослідження.}

Детальний аналіз Закону № 2498-VIII дозволив нам оцінити процедуру формування масиву земель сільськогосподарського призначення для забезпечення раціонального використання земельних ділянок за рахунок запровадження обміну прав користування як альтернативи консолідації земель. В результаті чого, вперше складено алгоритм формування масивів земель сільськогосподарського призначення щодо обміну земельними ділянками та правами їх користування, який дав змогу більш структуровано і комплексно підійти до вирішення поставленої проблематики.

Так, було доведено, що дозволений обмін земельними ділянками та правами користування в межах масиву земель сільськогосподарського призначення не $є$ консолідацією земель ані у класичному, ані у будь-якому іншому ï розумінні. Консолідація земель, використовуючи різні інструменти землеустрою, допомагає землевласникам та землекористувачам покращити просторові характеристики та умови використання земельних ділянок за рахунок зменшення рівня фрагментації земель та збільшення розмірів землекористування. Проте, запропонований Законом № 2498-VIII механізм усунення черезсмужжя та раціональної організації земельних ділянок цього не забезпечує.

За результатами оцінки, досліджений Закон № 2498-VIII не відповідає “Добровільним керівним принципами відповідального управління з питань володіння та користування земельними, рибними та лісовими ресурсами у контексті національної продовольчої” та кращій міжнародній практиці щодо консолідації земель. Окремі положення відповідного закону не відповідають таким основним принципам ДКП, як:

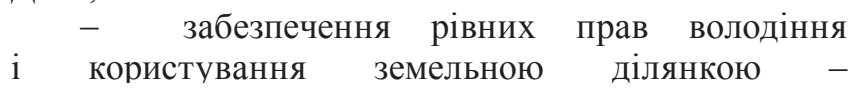


землекористувачу надається більше прав ніж землевласнику, особливо це стосується положення примусового укладання договору оренди (суборенди) в порядку обміну правами користування земельними ділянками в судовому порядку;

консультації і широкої участі - не закріплена процедура щодо врахування існуючого (можливого) дисбалансу сил між різними зацікавленими сторонами МЗСП і забезпечення активної, вільної, ефективної, осмисленої та поінформованої участі окремих осіб і груп у відповідних процесах прийняття рішень;

- прозорості - відсутній чіткий механізм оскарження учасниками МЗСП дій i рішень ініціатора(ів) формування МЗСП, виконавців інвентаризації МЗСП, планувальника/підрядника обміну земельними ділянками та правами їх користування або інших осіб у разі виникнення необхідності, а також не закріплений структурований порядок обігу прав користування i обміну земельними ділянками в межах МЗСП як альтернативи консолідації земель;

- цілісний i стійкий підхід до використання природних ресурсів - призначення формування МЗСП є дуже вузьким і спрямоване лише на усунення черезсмужжя для забезпечення раціонального використання земельних ділянок найбільш обмеженим способом, навіть невраховуючі розвитку і покращення об'єктів сільськогосподарської інфраструктури;

відповідальності і підзвітності - чітко не визначений порядок регулювання відповідальності усіх учасників процесу прийняття рішень щодо раціонального використання земельних ділянок в межах МЗСП.

Проведений аналіз існуючих перешкод, які заважають реалізації норм законодавства щодо удосконалення правил землекористування у масивах земель сільськогосподарського призначення, дозволив виділити три ключові причини їх виникнення: технічну, юридичну та організаційну. Технічною перешкодою є відсутність можливості занесення відомостей до Державного земельного кадастру про МЗСП і присвоєння йому облікового номера об'єкта Держаного земельного кадастру, що унеможливлює проведення раціональної організації земельних ділянок задля усунення черезсмужжя та отримання статусу істотного землекористувача. До основних юридичних перешкод слід віднести відсутність правових норм щодо: обміну правами користування земельними ділянками в межах МЗСП, які не можуть передаватися у вторинне користування (емфітевзис та постійне користування); визначення замовника технічної документації із землеустрою щодо інвентаризації земель у випадку, коли ініціатором інвентаризації МЗСП виступатиме група землевласників та/або землекористувачів; порядку погодження між усіма зацікавленими сторонами i процедури передачі у користування земельних ділянок державної чи комунальної власності під польовими дорогами; чіткого переліку необхідних документівдля отримання рішення про проведення інвентаризації МЗСП; процедури розробки плану обміну (міни) і оренди (суборенди) земельними ділянками; обміну земельними ділянками, які розташовані у різних МЗСП. Організаційними перешкодами є бюрократично обтяжлива процедура отримання статусу істотного землекористувача та значні фінансові й часові витрати на проведення інвентаризації земель і формування усіх земельних ділянок в межах МЗСП.

Прийнятий в умовах мораторію на продаж та відчуження земельних ділянок сільськогосподарського призначення Закон № 2498-VIII, на наше переконання, так і не став альтернативою консолідації земель, а з відкриттям ринку землі у липні 2021 р. його законодавчі норми не стануть на заваді збільшення рівня фрагментації земель. Вельми необхідно до запровадження ринку земель розробити Національну стратегію 3 консолідації земель для інтеграції інструменту консолідації земель до загальної земельної політики країни та повноцінний відповідний закон.

Однією з цікавих тем, яка виявилася під час проведення даного дослідження, є взаємовідносини між орендодавцем i орендарем. Статус орендодавця часто залишається невивченим, особливо під час проведення консолідації земель та/або обміну правами користування земельними ділянками. Можливо, в Україні існує загальна думка, що статус орендодавця $є$ захищеним i не може бути об'єктом дослідження. Однак, коли більше 90 \% посівних площ орендуються сільськогосподарськими підприємствами (Popov, 2016b), це означає, що до процесу консолідації земель буде залучено безліч орендодавців. Таким чином, вивчення статусу орендодавця у порівнянні 3 іншими групами зацікавлених осіб при проведенні консолідації земель є актуальним напрямком проведення майбутніх досліджень.

\section{References:}

FAO. (2003). Operations manual for land consolidation pilot projects in Central and Eastern Europe. Retrieved from http://www.fao.org/3/a-ai142e.pdf

FAO. (2004). The design of land consolidation pilot projects in Central and Eastern Europe. Food and Agriculture Organization. FAO Land Tenure Studies No. 6, Rome. Retrieved from ftp://ftp.fao.org/docrep/fao/006/Y4954E/ Y4954E00.pdf

FAO. (2012). Voluntary Guidelines on the Responsible Governance of Tenure of Land, Fisheries and Forests in the Context of National Food Security. Rome: FAO.

Hartvigsen, M. (2014). Land Reform and land fragmentation in Central and Eastern Europe. Land Use Policy, 36, 330-341. doi: 10.1016/j.landusepol.2013.08.016 
Hartvigsen, M. (2015). Integrated voluntary land consolidation - A Third model for land consolidation in Central and Eastern Europe. FAO Land Tenure Journal, 1-2015, 9-43.

Hartvigsen, M., Versinskas, T., Vidar, M., Mitic Arsova, K., Van Holst, F. \& Gorgan, M. (2019). FAO recommendation on land consolidation legislation. Paper presented at the 2019 World Bank Conference on Land and Poverty, Washington, DC, March 25-29, 2019.

Hartvigsen, M. (2015a). Land Reform and Land Consolidation in Central and Eastern Europe after 1989: Experiences and Perspectives (Doctoral dissertation). Retrieved from https://www.academia.edu

Kulinich, O. (2018, August 23). The law on land consolidation has been signed. What changes are awaiting us? [A column in the Newspaper]. Retrieved from https://www.epravda.com.ua/columns/2018/08/23/639841/ [in Ukrainian]. [Кулініч О. Закон про консолідацію земель підписано. Які зміни нас чекають? Економічна правда : веб-сайт. URL: https://www.epravda.com.ua/columns/2018/08/23/639841/ (дата звернення: 09.11.2020).]

Maksymenko, M. (2019, August). Consolidation of Agricultural Land. Business Law, 7-8. Retrieved from https:// pravo.ua/articles/consolidation-of-agricultural-land/

Martyn, A., Krasnolutskyi, O. (2011). Agricultural Land Consolidation and the Legal Mechanisms of Its Implementation in Ukraine. Zemlevporiadnyi visnyk, 5, 16-21 [in Ukrainian]. [Мартин А., Краснолуцький О. Консолідація земель сільськогосподарського призначення та правові механізми їі здійснення в Україні // Землевпорядний вісник. 2011. № 5. С. 16-21.]

Popov, A., Koshkalda, I. Kniaz, O., \& Trehub, O. (2019). Land fragmentation of agricultural enterprises in the context of administration of land. Economic Annals-XXI, 176 (3-4), 80-90. doi: 10.21003/ea.V176-08

Popov, A. (2016a). The Scientific Approaches to Definition of Agricultural Land Consolidation. Zemlevporiadnyi visnyk, 3, 31-35. [in Ukrainian]. [Попов А. Наукові підходи щодо визначення поняття консолідації земель сільськогосподарського призначення // Землевпорядний вісник. 2016. № 3. С. 31-35.]

Popov, A. (2016b). The Current Condition and Main Tendencies of Agricultural Land Use. Efektyvna ekonomika, 2. Retrieved from http://www.economy.nayka.com.ua/?op=1\&z=4775 [in Ukrainian]. [Попов А. Сучасний стан i основні тенденції використання земель сільськогосподарського призначення // Ефективна економіка. 2016. № 2. URL: http://www.economy.nayka.com.ua/?op=1\&z=4775]

Ruden, O. (2017). Agricultural Land Consolidation - New Suggestions from the Legislative Branch of Government. Young Scientist, 8, 380-384. [in Ukrainian]. [Рудень О. В. Консолідація земель сільськогосподарського призначення - нові пропозиції законодавця // Молодий Вчений. 2017. № 8. С. 380-384. ]

Shvorak, A., Yevsiukov, T. (2014). Methods and Techniques of the Agricultural Land Consolidation. Ekonomist, 8, 44-48. [in Ukrainian]. [Шворак А., Євсюков Т. Способи та методи консолідації земель сільськогосподарського призначення // Економіст. 2014. № 8. С. 44-48.]

Slaston, R. (2020, October 16). Earth gravity. The five most ambitious agribusiness expectations in the land sector [Web log post]. Retrieved from https://lb.ua/blog/roman_slaston/468254_zemne_tyazhinnya_pyat_nayambitnishih.html [in Ukrainian]. [Сластьон Р. Земне тяжіння. П'ять найамбітніших очікувань агробізнесу в земельній сфері. LB.иа : веб-сайт. URL: https://lb.ua/blog/roman_slaston/468254_zemne_tyazhinnya_pyat_nayambitnishih. html (дата звернення: 09.11.2020).]

Stupen, M., Dudych, H. (2015). Lease as a Form of Land Consolidation. Ekonomist, 7, 34-37. [in Ukrainian]. [Ступень М., Дудич Г. Оренда як форма консолідації земель // Економіст. 2015. № 7. С. 34-37.]

Sulonen, K., Kotilainen, S. (2015). Lessor's Status in Land Consolidation in Europe - Reports from Cyprus, Finland, France, Germany, the Netherlands, Latvia and Estonia. Baltic Journal of Real Estate Economics and Construction Management, 3, 56-71. doi: 10.1515/bjreecm-2015-0007

Thomas, J. (2006). Attempt on Systematization of Land Consolidation Approaches in Europe. Zeitschrift für Geodäesie, Geoinformation und Landmanagement, 3, 156-161.

Thomas, J. (2006a). What's on Regarding Land Consolidation in Europe? Proceedings of the XXIII FIG Congress, Shaping the Change, October 8-13, 2006, Munich, Germany. Retrieved from http://www.fig.net/pub/fig2006/papers/ ts80/ts80 03 thomas_0311.pdf

Van Dijk , T. (2003). Dealing with Central European Land Fragmentation. The Netherlands: Uitgeverij Eburon.

Van Dijk T. (2007). Complications for traditional land consolidation in Central Europe. Geoforum, 38 (3), $505-511$.

Veršinskas, T., Vidar, M., Hartvigsen, M., Mitic Arsova, K., van Holst, F. and Gorgan, M. (2020). Legal guide on land consolidation: Based on regulatory practices in Europe. FAO Legal Guide, No. 3. Rome, FAO. doi: $10.4060 /$ ca9520en

VRU. Verkhovna Rada Ukrainy. (1996). Constitution of Ukraine, 28.06.1996. Retrieved from https://zakon. rada.gov.ua/laws/show/254\%D0\%BA/96-\%D0\%B2\%D1\%80\#Text [in Ukrainian]. [Конституція України від 28 черв. 1996. URL: https://zakon.rada.gov.ua/laws/show/254\%D0\%BA/96-\%D0\%B2\%D1\%80\#Text (дата звернення: 09.11.2020).]

VRU. Verkhovna Rada Ukrainy. (1998). On Land Lease: Law of Ukraine, 06.10.1998, No.161-XIV.Retrieved from https://zakon.rada.gov.ua/laws/show/161-14/print [in Ukrainian]. [Про оренду землі : Закон України від 6 жовт. 1998 p. № 161-XIV.URL: https://zakon.rada.gov.ua/laws/show/161-14/print (дата звернення: 09.11.2020).]

VRU. Verkhovna Rada Ukrainy. (2003). On Land-Use Planning: Law of Ukraine, 22.05.2003, No.858-IV. Retrieved from https://zakon.rada.gov.ua/laws/show/858-15/print[in Ukrainian]. [Про землеустрій : 
Закон України від 10 трав. 2003 р. № 858-IV.URL: https://zakon.rada.gov.ua/laws/show/858-15/print (дата звернення: 09.11.2020).]

VRU. Verkhovna Rada Ukrainy. (2018). On Amendments to Certain Legislative Acts of Ukraine in Respect of the Issue of Collective Ownership of Land, Improvement of Agricultural Land Use Rules, Prevention of Raidership and Stimulation of Irrigation in Ukraine: Law of Ukraine, 10.07.2018, No.2498-VIII. Retrieved from https://zakon. rada.gov.ua/laws/show/2498-19\#Text [in Ukrainian]. [Про внесення змін до деяких законодавчих актів щодо вирішення питання колективної власності на землю, удосконалення правил землекористування у масивах земель сільськогосподарського призначення, запобігання рейдерству та стимулювання зрошення в Україні : Закон України від 10 лип. 2018 р. № 2498-VIII.URL: https://zakon.rada.gov.ua/laws/show/2498-19\#Text (дата звернення: 09.11.2020).]

Yurchenko, E. (2020, June 4). Land Consolidation: let's get it started [Web log post]. Retrieved from https:// agroportal.ua/ua/views/blogs/konsolidatsiya-zemel-lets-get-it-started/\# [in Ukrainian]. [Юрченко Е. Консолідація земель. let's get it started. Agroportal: веб-сайт. URL: https:/agroportal.ua/ua/views/blogs/konsolidatsiya-zemellets-get-it-started/\# (дата звернення: 09.11.2020).]

Zemelnyi kodeks. (2001). Land Code of Ukraine, 25.10.2001, No. 2768-III. Retrieved from http://zakon.rada.gov. ua/laws/show/2768-14 [in Ukrainian]. [Земельний кодекс України від 10 трав. 2003 p. № 2768-III.URL: https:// zakon.rada.gov.ua/laws/show/858-15/print (дата звернення: 09.11.2020).] 